\title{
Regulating DNA Replication in Bacteria
}

\author{
Kirsten Skarstad ${ }^{1}$ and Tsutomu Katayama ${ }^{2}$ \\ ${ }^{1}$ Department of Cell Biology, Institute for Cancer Research, The Radium Hospital, Oslo University \\ Hospital, 0310 Oslo, Norway \\ ${ }^{2}$ Department of Molecular Biology, Graduate School of Pharmaceutical Sciences, Kyushu University, \\ Fukuoka 812-8582, Japan \\ Correspondence: katayama@phar.kyushu-u.ac.jp
}

The replication origin and the initiator protein DnaA are the main targets for regulation of chromosome replication in bacteria. The origin bears multiple DnaA binding sites, while DnaA contains ATP/ADP-binding and DNA-binding domains. When enough ATP-DnaA has accumulated in the cell, an active initiation complex can be formed at the origin resulting in strand opening and recruitment of the replicative helicase. In Escherichia coli, oriC activity is directly regulated by DNA methylation and specific oriC-binding proteins. DnaA activity is regulated by proteins that stimulate ATP-DnaA hydrolysis, yielding inactive ADP-DnaA in a replication-coupled negative-feedback manner, and by DnaA-binding DNA elements that control the subcellular localization of DnaA or stimulate the ADP-to-ATP exchange of the DnaA-bound nucleotide. Regulation of $d n a A$ gene expression is also important for initiation. The principle of replication-coupled negative regulation of DnaA found in $E$. coli is conserved in eukaryotes as well as in bacteria. Regulations by oriC-binding proteins and $d n a A$ gene expression are also conserved in bacteria.

B acteria typically contain few chromosomes, each carrying a defined origin of replication (Messer 2002). The model bacteria referred to in this work (Escherichia coli, Bacillus subtilis, Caulobacter crescentus, and Helicobacter pylori) all have a single circular chromosome that is replicated bidirectionally from the origin. Some bacteria, for instance E. coli and B. subtilis, grow with overlapping replication cycles in rich media (Fig. 1) (Kornberg and Baker 1992; Helmstetter 1996). This allows for cell doubling times that are shorter than the replication phase, and requires replication initiation to occur at 2, 4, or 8 origins, depending on the growth rate. Replica- tion timing is maintained such that initiation occurs simultaneously at all origins once per generation (Skarstad et al. 1986).

The key protein responsible for DNA strand opening at the origin and for the recruitment of replisome components is the initiator protein, DnaA (Kornberg and Baker 1992; Messer 2002; Duderstadt and Berger 2008; Ozaki and Katayama 2009; Kaguni 2011; Leonard and Grimwade 2011). DnaA is an $\mathrm{AAA}^{+}$type protein that binds ATP and ADP with high affinity. DnaA binds to high- and low-affinity sites in oriC and forms an oligomeric structure (Fig. 2) (Grimwade et al. 2000; Kawakami et al. 2005;

Editors: Stephen D. Bell, Marcel Méchali, and Melvin L. DePamphilis

Additional Perspectives on DNA Replication available at www.cshperspectives.org

Copyright (C) 2013 Cold Spring Harbor Laboratory Press; all rights reserved; doi: 10.1101/cshperspect.a012922

Cite this article as Cold Spring Harb Perspect Biol 2013;5:a012922 

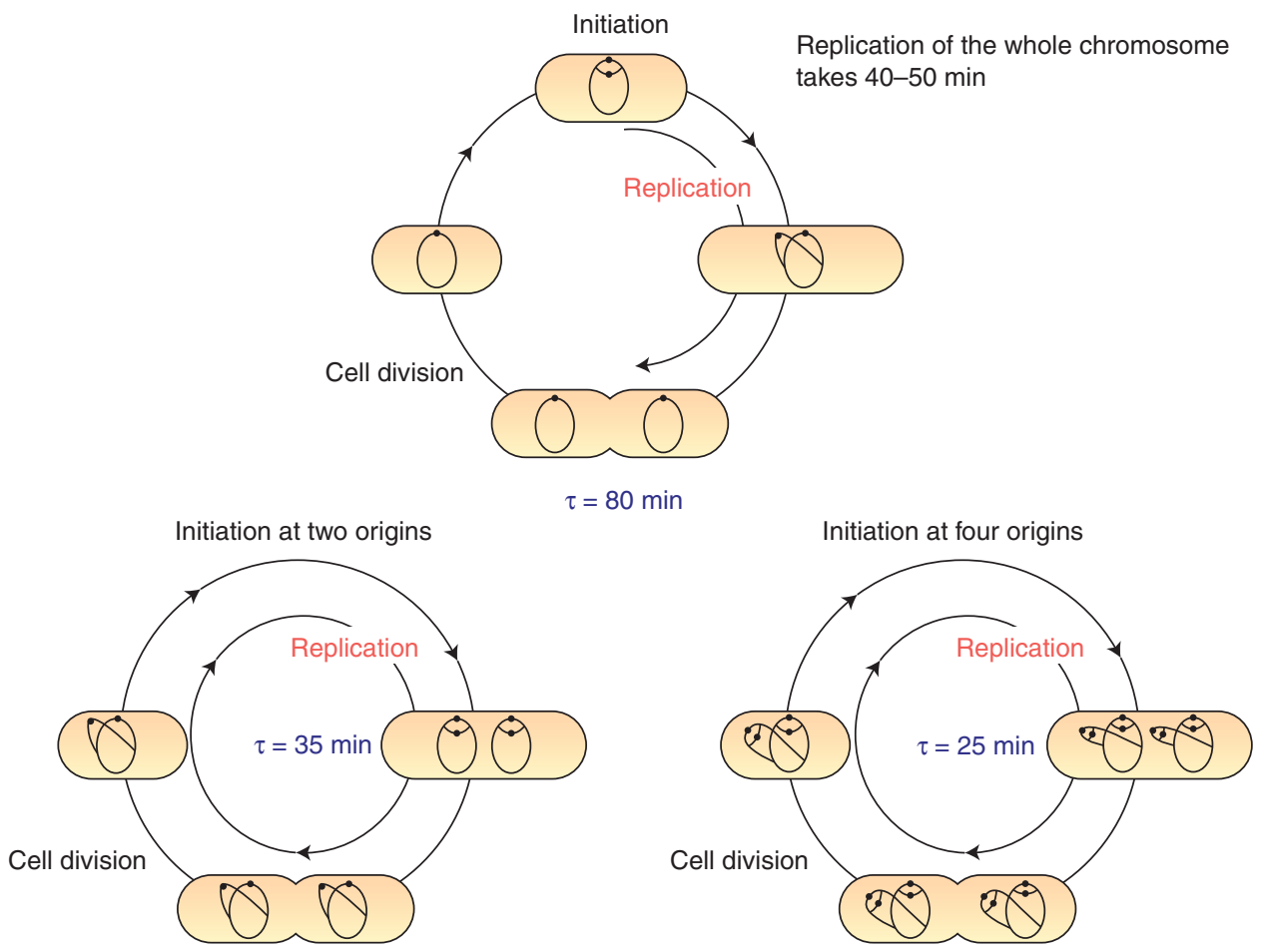

Figure 1. The replication cycle of the E. coli chromosome in slowly and rapidly growing cells. The chromosomal replication cycle and the cell division cycle in E. coli are shown. When cells are growing slowly (in this example, the doubling time $\tau$ is $80 \mathrm{~min}$ ), cell division occurs after replication of the sister chromosomes is completed. When cells are growing rapidly (i.e., $\tau$ is 35 or $25 \mathrm{~min}$ ), replication initiation simultaneously occurs at each oriC on the partially replicated chromosomes, and cell division occurs after the previous round of replication has been completed. Closed circles, oriC.

Erzberger et al. 2006; Kawakami and Katayama 2010) that involves two types of DnaA-DNA interactions, one with double-stranded and one with single-stranded DNA (Speck and Messer 2001; Fujikawa et al. 2003; Ozaki et al. 2008; Duderstadt et al. 2011; Ozaki and Katayama 2012). Only the ATP-bound form of DnaA is capable of binding to low-affinity sites (Fig. 2), which is supported by specific interDnaA interaction mediated through its $\mathrm{AAA}^{+}$ domain, resulting in the nucleoprotein structures required for initiation activity (McGarry et al. 2004; Kawakami et al. 2005). Like ATPDnaA, ADP-DnaA binds to high-affinity 9mer DnaA boxes through its carboxy-terminal dsDNA binding domain, but forms multimers on oriC that are structurally distinct from those of ATP-DnaA. The binding of IHF, another pos- itive regulator of initiation, to oriC induces a 180 degree bend in the DNA (Dillon and Dorman 2010) and plays an important role in forming an optimal initiation complex (Hwang and Kornberg 1992; Hiasa and Marians 1994; Cassler et al. 1995; Grimwade et al. 2000; Ryan et al. 2002; Leonard and Grimwade 2005; Ozaki and Katayama 2012). Other nucleoid-associated proteins (HU and Fis) also affect formation of the initiation complex (Fig. 3) (Gille et al. 1991; Hwang and Kornberg 1992; Hiasa and Marians 1994; Cassler et al. 1995; Wold et al. 1996; Margulies and Kaguni 1998; Ryan et al. 2002, 2004). Transcription by RNA polymerase is required for replication initiation (Kornberg and Baker 1992), though the mechanism by which this occurs remains unclear. Transcription in or around oriC is thought to facilitate opening of 


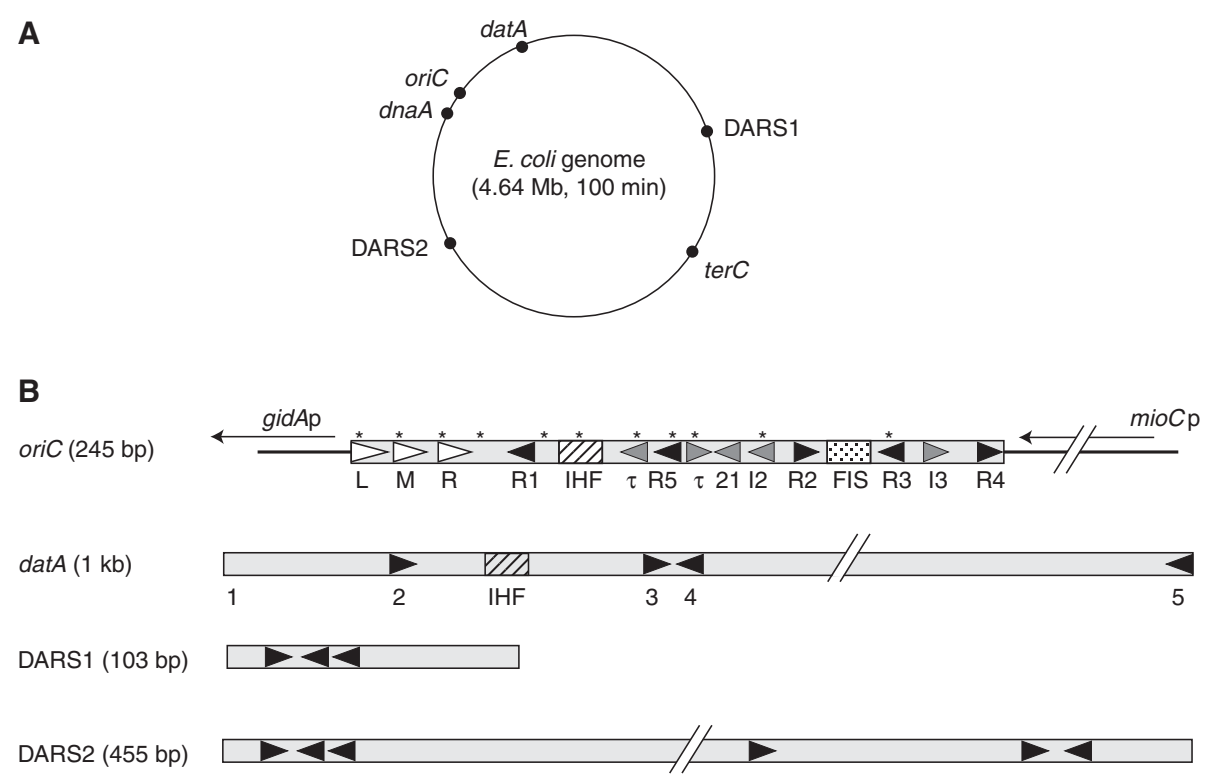

Figure 2. Structures of oriC, datA, and DARSs. (A) The E. coli chromosome is shown as a circle and the locations of oriC (at the genome map position of $84.6 \mathrm{~min}$ ), dnaA (at $83.6 \mathrm{~min}$ ), datA (at $94.6 \mathrm{~min}$ ), DARS1 (at $17.5 \mathrm{~min}$ ), DARS2 (at $64.0 \mathrm{~min}$ ), and $\operatorname{ter} C$ (around $36 \mathrm{~min}$ ) are indicated. (B) Basic structures of oriC, datA, and DARSs are schematically shown. Closed triangle, DnaA box (9-nucleotide sequence). Gray triangle, I-sites, and $\tau$-sites (both 6-nucleotide sequence). As for datA, DnaA boxes 2 and 3 are most crucial in repression of initiation (Ogawa et al. 2002). For details on low-affinity DnaA binding sites in datA, see Hansen et al. (2007). Open triangle, 13-mer AT-rich motif within DUE. IHF, IHF-binding site; FIS, FIS-binding site; *, GATC sequence within oriC.

the DNA strands, and may be a prerequisite for initiation in vivo under certain conditions, for instance, when nucleoid-associated proteins partially restrain negative superhelicity, thereby impeding strand opening (Baker and Kornberg 1988; Skarstad et al. 1990; Bates et al. 1997). In some circumstances, transcription through oriC may also be inhibitory (Su' etsugu et al. 2003) and for such transcription, the DnaA protein functions as a transcriptional regulator (Weigel and Messer 1997; Flåtten et al. 2009). Thus, DnaA has two roles at oriC, one as an initiator and the other as a transcription regulator.

After the DNA strands at oriC are separated, the DnaB helicase, bound to the helicase loader $\mathrm{DnaC}$, is recruited to the initiation complex via interactions with oriC-bound DnaA (Sutton et al. 1998; Seitz et al. 2000; Messer 2002; Abe et al. 2007; Duderstadt and Berger 2008; Leonard and Grimwade 2010; Kaguni 2011). This stage may involve a reorganization of the DnaA-
oriC complex and is influenced by the DiaA protein (Fig. 3) (Keyamura et al. 2009). DiaA binds to the amino terminus of DnaA and promotes initiation (Ishida et al. 2004; Keyamura et al. 2007). DiaA may also have a modulating effect on DnaB loading, because it binds to DnaA in the same place as DnaB, and inhibits loading of DnaB in vitro (Keyamura et al. 2009).

Regulation of initiation must fulfill two requirements. It must prevent extra initiation events, and it must ensure sufficient initiation so that one initiation event occurs per generation per origin. Several mechanisms ensure that extra initiation events do not occur (described below), but less is known about the timing of replication initiation, i.e., the rate-limiting steps, and whether the same factor(s) are required under all conditions. The frequency of replication must match the growth rate, otherwise the cellular DNA concentration will be altered. The cellular concentration of DnaA 
K. Skarstad and T. Katayama

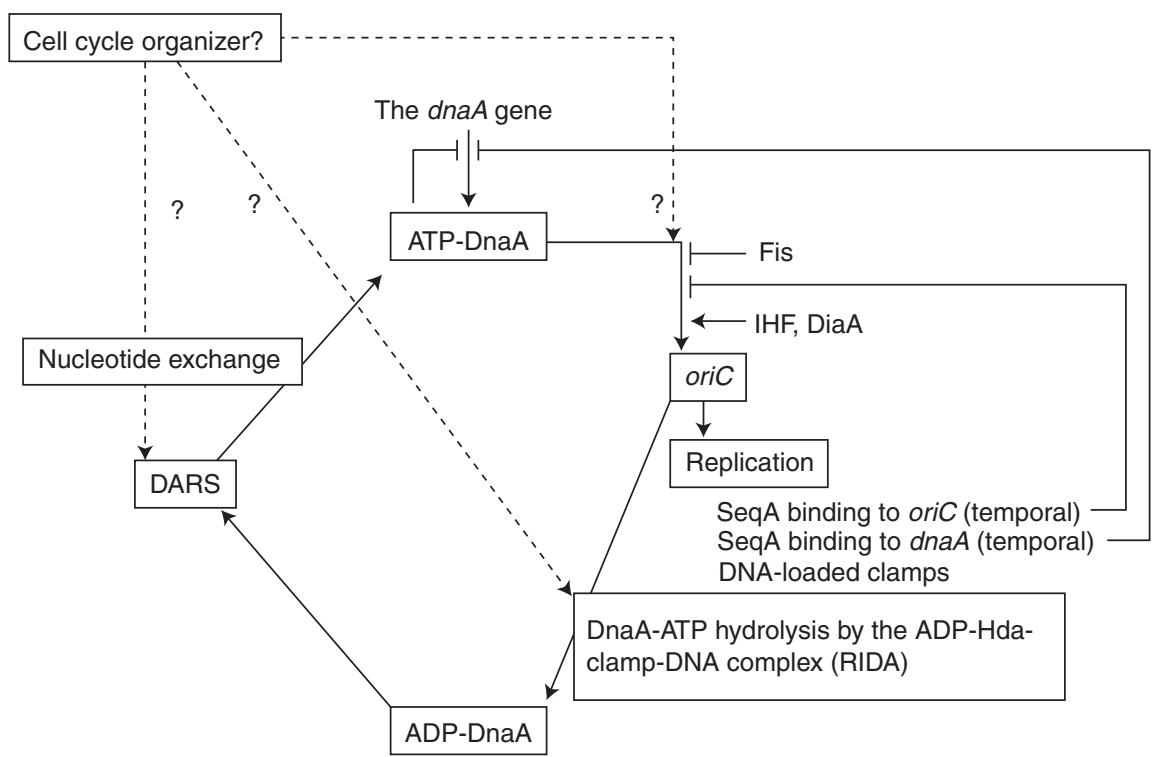

Figure 3. The DnaA cycle and regulation of oriC initiation. Transcription of the $d n a A$ gene is autoregulated. ATPDnaA is more active in inhibiting $d n a A$ transcription than ADP-DnaA. Also, $d n a A$ transcription increases before replication initiation and is repressed after it in a SeqA-dependent manner. Newly synthesized DnaA molecules adopt the ATP form. ATP-DnaA molecules are also generated by nucleotide exchange of ADP-DnaA in a DARSdependent manner, though the cell cycle-dependent regulation of DARS remains unclear. With the assistance of DiaA and IHF, ATP-DnaA molecules form a multimeric complex on oriC in a cooperative manner. The resultant oriC complex unwinds DUE and is then engaged in replisome formation. The clamps remain on the synthesized DNA after Okazaki fragments are synthesized and form a complex with ADP-Hda, which interacts with and promotes the hydrolysis of ATP-DnaA (i.e., RIDA). Broken lines indicate expected but unrevealed pathways for cell cycle-coordinated regulation.

protein was found to be constant irrespective of the growth media (Hansen et al. 1991a) and a theoretical model has suggested that the production of DnaA couples growth rate to replication frequency (Hansen et al. 1991b). The ratio of ATP-DnaA to ADP-DnaA varies throughout the cell cycle and peaks right before replication initiation (Kurokawa et al. 1999). It has therefore been suggested that the frequency of initiation is determined by the accumulation of ATP-DnaA at oriC during steady-state growth (Donachie and Blakely 2003).

\section{REGULATION AT THE ORIGIN \\ SEQUENCE IN E. coli}

\section{Origin Sequestration}

There are, in principle, two ways to prevent excess initiation of replication, one is to hinder origin usage, and the other is to inactivate the factors that perform initiation. In E. coli, origin usage is prevented by a process called origin sequestration that depends on the binding of the SeqA protein to newly replicated origins (Fig. 3; Table 1) (Lu et al. 1994; Slater et al. 1995; Brendler and Austin 1999; Waldminghaus and Skarstad 2009). Lack of SeqA causes untimely extra initiations and asynchrony in initiation of multiple origins (i.e., asynchrony phenotype).

SeqA discriminates between new and old origins by the methylation status of GATC sequences, which are present at high frequency in the oriC DNA sequence. The adenines of these sequences are recognized and methylated by Dam methylase. Chromosomal GATC sites remain hemimethylated for about a minute after the replication fork has passed (Campbell and Kleckner 1990). The high frequency of GATC sites in the origin (Fig. 2), however, 
Table 1. Regulatory pathways for replication initiation

\begin{tabular}{|c|c|c|c|c|}
\hline $\begin{array}{l}\text { Regulation } \\
\text { in E. coli }\end{array}$ & $\begin{array}{l}\text { Target of } \\
\text { regulation }\end{array}$ & $\begin{array}{l}\text { Representative } \\
\text { regulatory factor }\end{array}$ & $\begin{array}{c}\text { Representative phenotype } \\
\text { when regulation is } \\
\text { disrupted }\end{array}$ & $\begin{array}{l}\text { Possible analogs in } \\
\text { other organisms }\end{array}$ \\
\hline Sequestration & oriC & SeqA & $\begin{array}{l}\text { Extra initiations, } \\
\text { asynchrony phenotype }\end{array}$ & $\begin{array}{l}\text { Regulation by Soj in } \\
\text { B. subtilis } \\
\text { Regulation by CtrA in } \\
\text { C. crescentus }\end{array}$ \\
\hline dnaA transcription & $d n a A$ gene & DnaA, SeqA & $\begin{array}{l}\text { Extra initiations, } \\
\text { asynchrony phenotype } \\
\text { (when SeqA function is } \\
\text { inhibited or dnaA is } \\
\text { overexpressed) }\end{array}$ & $\begin{array}{l}\text { dnaA autoregulation in } \\
\text { B. subtilis } \\
\text { Cell cycle-coupled } \\
\text { transcription in } \\
\text { C. crescentus }\end{array}$ \\
\hline $\begin{array}{l}\text { Binding of DnaA to } \\
\text { sites other than } \\
\text { oriC }\end{array}$ & DnaA & $\operatorname{dat} A$ & $\begin{array}{l}\text { Extra initiations, changed } \\
\text { timing in some growth } \\
\text { conditions, asynchrony } \\
\text { phenotype }\end{array}$ & $\begin{array}{l}\text { Regulation by DnaA box } \\
\text { clusters in B. subtilis and } \\
\text { Streptomyces coelicolor }\end{array}$ \\
\hline DnaA reactivation & ADP-DnaA & DARS & $\begin{array}{l}\text { Inhibition of initiation, } \\
\text { asynchrony phenotype }\end{array}$ & $\begin{array}{l}\text { Unknown, but DARS- } \\
\text { homologous sequences } \\
\text { are conserved in certain } \\
\text { bacterial genomes } \\
\text { (Fujimitsu et al. 2009) }\end{array}$ \\
\hline $\begin{array}{l}\text { Stimulation of } \\
\text { DnaA } \\
\text { multimerization }\end{array}$ & ATP-DnaA & DiaA & $\begin{array}{l}\text { Inhibition of initiation, } \\
\text { asynchrony phenotype }\end{array}$ & $\begin{array}{l}\text { Regulation by HobA in } \\
\text { H. pylori }\end{array}$ \\
\hline $\begin{array}{l}\text { DnaA inactivation } \\
\text { (RIDA) }\end{array}$ & ATP-DnaA & Hda & $\begin{array}{l}\text { Severe amount of extra } \\
\text { initiations, asynchrony } \\
\text { phenotype } \\
\text { Inhibition of cell division } \\
\text { and cell proliferation }\end{array}$ & $\begin{array}{l}\text { Regulation by YabA-clamp } \\
\text { complex in B. subtilis } \\
\text { Regulation by HdaA-clamp } \\
\text { complex in C. crescentus } \\
\text { Regulation by Cul4-DDB1- } \\
\text { PCNA (clamp) complex } \\
\text { in eukaryotes }\end{array}$ \\
\hline
\end{tabular}

results in origin DNA remaining hemimethylated for about a third of a generation after replication (Campbell and Kleckner 1990; Lu et al. 1994; Bach and Skarstad 2005). During this time, the origin is bound by SeqA, which, in addition to preventing GATC methylation by Dam methylase, inhibits replication initiation (Fig. 3; Table 1) (Lu et al. 1994; Boye et al. 1996; Guarne et al. 2002; Fujikawa et al. 2004). Also, DnaA itself contributes to origin sequestration, probably by hindering remethylation by Dam at some of the GATC sites in oriC ( $\mathrm{Lu}$ et al. 1994; Bach et al. 2008). In vitro, SeqA forms fibers of head-to-head dimers (Guarne et al. 2005; Kang et al. 2005; Odsbu et al. 2005). Additionally, the binding of SeqA multimers to oriC can alter DNA superhelicity (Torheim et al. 1999) and inhibit ATP-DnaA binding to lowaffinity sites (Nievera et al. 2006), both of which can inhibit the initiation reaction (Fig. 3; Table 1) (Lee et al. 2001; Waldminghaus and Skarstad 2009).

Microscopy of fluorescently labeled SeqA indicates that the majority of cellular SeqA forms relatively compact structures with the hemimethylated DNA at replication forks ( $\mathrm{Hi}-$ raga 1998, 2000; Brendler et al. 2000; Molina and Skarstad 2004; Yamazoe et al. 2005; Fossum et al. 2007). These structures are dynamic and trail the replication forks, and always bind to the most newly synthesized DNA (Yamazoe et al. 2005; Waldminghaus et al. 2012). Because extra SeqA foci representing sequestered origins have not been detected, it has been suggested that 
sequestered origins bound by SeqA are situated at, or near, the replication fork structures (Molina and Skarstad 2004; Bach and Skarstad 2005; Morigen et al. 2009).

Regulation by Transcription at and near the Origin

Transcription around and at oriC can affect replication initiation and may also contribute to regulation of initiation frequency. The mioC and gidA genes are located at the right and left side of oriC, respectively (Fig. 2). The mioC gene does not have a strong terminator and its transcripts read through oriC (Messer and Weigel 1997). The gidA gene is transcribed away from oriC. The mioC promoter region contains a DnaA box cluster and DnaA binding negatively regulates mioC gene transcription (Messer and Weigel 1997; Hansen et al. 2007). Transcription of mioC is repressed before replication initiation and is derepressed after it (Theisen et al. 1993; Ogawa and Okazaki 1994; Bogan and Helmstetter 1997). Constitutive transcription of mioC impedes initiation (Su'etsugu et al. 2003). The transcriptional pattern of gidA is opposite to that of mioC (Theisen et al. 1993; Ogawa and Okazaki 1994; Bogan and Helmstetter 1997). Deleting the promoters of these genes does not affect initiation regulation in wild type cells during steadystate growth, although the transcription of these genes can stimulate initiation in cells bearing a mutation impeding initiation (Bates et al. 1997).

\section{REGULATION OF THE DnaA \\ PROTEIN IN E. coli}

\section{Overview}

The production and activity of E. coli DnaA protein is regulated in several ways: by transcription, intracellular localization, and conformation (Katayama et al. 2010; Leonard and Grimwade 2010; Kaguni 2011). DnaA protein is stable, but replication cycle-specific dnaA gene transcription is important for sustaining well-timed initiation of replication (Bogan and Helmstetter 1997; Riber and Løbner-Olesen 2005). This can be explained by the role of ATP-DnaA in activat- ing initiation (Kurokawa et al. 1999; Nishida et al. 2002) and the idea that newly synthesized DnaA preferentially binds ATP, the cellular level of which is 10-fold higher than that of ADP (Fig. 3).

Also, timely initiation of replication during the cell cycle requires specific chromosomal regions termed DARS (DnaA-reactivating sequence) 1 and DARS2. These regions bind ADP-DnaA molecules and promote the regeneration of ATP-DnaA by nucleotide exchange (Figs. 2 and 3) (Fujimitsu et al. 2009).

It has been estimated that there are 5002000 DnaA molecules per cell, depending on strain backgrounds and growth rates (Sekimizu et al. 1988; Chiaramello and Zyskind 1989; Hansen et al. 1991a). oriC can bind 10-20 DnaA molecules (Messer 2002). A considerable number of DnaA molecules can be titrated at a specific chromosomal locus termed datA that is required for repressing rifamcipin-resistant unregulated initiation events (Figs. 2 and 3) (Kitagawa et al. 1998; Morigen et al. 2005).

The ATP-DnaA level fluctuates during the replication cycle, peaking around the time of initiation (Kurokawa et al. 1999). ATP-DnaA hydrolysis is required to reduce ATP-DnaA levels after initiation (Fig. 3). This regulation, termed RIDA (regulatory inactivation of DnaA), is coupled with the action of the DNA polymerase III holoenzyme. RIDA is crucial for regulating initiation so that it occurs only once per generation (Katayama et al.1998; Kato and Katayama 2001; Su'etsugu et al. 2004; Camara et al. 2005).

\section{Regulation of DnaA Gene Transcription}

The cellular DnaA concentration was found to be constant irrespective of growth medium and the cell cycle (Hansen et al. 1991a). However, the transcription of the $d n a A$ gene varies in a replication cycle-dependent manner (Bogan and Helmstetter 1997). The main reason for the fluctuation seems to be that the $d n a A$ gene promoter is sequestered by SeqA for almost the same duration as the origin (Fig. 3; Table 1) (Campbell and Kleckner 1990; Lu et al. 1994; Riber and Løbner-Olesen 2005). During sequestration, the promoter is unavailable to the transcription machinery. Because the $d_{n a A}$ gene is situated 
near oriC, this contributes to reducing the production of DnaA and thus the initiation potential (i.e., the ability to initiate replication) soon after new replication forks have been launched (Riber and Løbner-Olesen 2005). The dnaA promoter area also contains DnaA boxes and the promoter was found to be capable of autoregulation (Fig. 3; Table 1) (Messer and Weigel 1997; Hansen et al. 2007). Translation of dnaA mRNA has not been well characterized, but it is known that the start codon, GTG, functions inefficiently in E. coli.

\section{Binding of DnaA to Sites Other than oriC}

As mentioned, the DnaA protein functions not only as the initiator but also as a gene regulatory protein. There are about 300 high-affinity DnaA binding sites and a very large number of lowaffinity sites around the chromosome (Kitagawa et al. 1996; Roth and Messer 1998; Hansen et al. 2007). As the chromosome is replicated, the DnaA binding sites are duplicated and contribute to titration of DnaA away from oriC. The main titration site, $\operatorname{dat} A$, is situated near oriC and is duplicated soon after initiation of replication (Kitagawa et al. 1996, 1998; Ogawa et al. 2002; Morigen et al. 2003, 2005). In vivo studies indicate that the datA site binds on average 60 DnaA molecules (Hansen et al. 2007). The datA site should therefore contribute to reducing the initiation potential at oriC when oriC is still in sequestration. The $d a t A$ site is about $1 \mathrm{~kb}$ in size and contains five high-affinity DnaA binding sites and about 25 low-affinity sites (Fig. 2; Table 1) (Kitagawa et al. 1996, 1998; Hansen et al. 2007). High-affinity DnaA boxes 2 and 3 are crucial for efficient binding of DnaA to datA. It is possible that the DnaA bound to these sites function as a core for further cooperative DnaA binding (Ogawa et al. 2002). The production of DnaA protein as cells grow and the generation of binding sites as the chromosome is replicated, as well as sequestration and RIDA, has been simulated in silico (Hansen et al. 1991; Browning et al. 2004; Atlas et al. 2008) and may indicate that initiation occurs as soon as enough ATP-DnaA has accumulated at oriC. However, cells with similar numbers of origins and chromosomal DnaA binding sites but different growth conditions have been reported to contain different amounts of DnaA per origin at initiation (Torheim et al. 2000; Flåtten et al. 2009). So, although origin firing as soon as enough ATP-DnaA has accumulated is an attractive model of cell cycle regulation, a complete understanding of regulation encompassing different growth conditions is still lacking even in the well-characterized E. coli bacterium.

\section{Regulation of the DnaA Nucleotide Form} by DARS and Acidic Phospholipids

E. coli cells can convert ADP-DnaA to ATPDnaA by nucleotide exchange (Fig. 3) (Kurokawa et al. 1999; Fujimitsu et al. 2009). The DARS1 and DARS2 sequences promote this reaction and are located halfway within the intergenic region between ori $C$ and $\operatorname{ter} C$, to the right and left of oriC, respectively (Fig. 2A) (Fujimitsu et al. 2009). A common feature of DARS1 and DARS2 is the presence of a DnaA box cluster, in which three DnaA boxes are similarly oriented and are located at a similar distance (Fig. 2B). Multiple ADP-DnaA molecules can form complexes with DARS, which facilitates the release of ADP from DnaA. The resultant apo-DnaA molecules are likely released from DARS because of reduced complex formation activity, which allows the binding of ATP and DnaA reactivation. Increasing the cellular copy number of DARS1 or DARS2 increases the ATP-DnaA level, inducing extra initiation events, whereas deleting both DARS1 and DARS2 causes a delay in initiation (Fujimitsu et al. 2009). Newly translated DnaA protein binds ATP, providing cells with a basal level of ATP-DnaA. However, this alone is not enough to initiate replication in a timely manner. Thus, the function of DARSs is crucial for timely initiation (Fig. 3; Table 1). Functional regulation of DARS remains to be clarified, except for the fact that each DARS contains a regulatory region in addition to the common sequence bearing the DnaA box cluster (Fujimitsu et al. 2009; Leonard and Grimwade 2009). In addition to DARS, acidic phospholipids such as cardiolipin and phosphatidylglycerol play an important role in the nucleotide 
release of ADP-DnaA (Sekimizu and Kornberg 1988), and DnaA is reactivated by exchange of the bound nucleotide in vitro in the presence of oriC and ATP (Crooke et al. 1992). Reduction of the acidic phospholipids in vivo can inhibit initiation at oriC (Xia and Dowhan 1995), but exactly how acidic phospholipids affect DnaA activity during the cell cycle remains to be elucidated.

\section{Regulation of DnaA Multimer Formation by DiaA}

DiaA forms homotetramers and each protomer contains a specific site for binding to DnaA domain I (Fig. 3) (Ishida et al. 2004; Keyamura et al. 2007, 2009). These features allow a single DiaA tetramer to bind multiple molecules of DnaA, which can stimulate cooperative binding of DnaA to oriC and the unwinding reaction (Fig. 3; Table 1). The binding of ATP-DnaA to low-affinity binding sites within oriC is enhanced by DiaA (Fig. 1) (see Bell and Kaguni 2013; Leonard and Méchali 2013). In diaA-disrupted mutant cells, replication initiation is delayed and initiation at sister oriC copies occurs asynchronously in rapidly growing cells (Ishida et al. 2004; Keyamura et al. 2007, 2009). These data are consistent with the observation that replication is initiated asynchronously in mutants bearing DnaA box R4-deleted oriC (Bates et al. 1995), because the binding of DnaA to high-affinity DnaA box R4 enhances cooperative DnaA binding to low-affinity sites.

After DUE unwinding in oriC complexes, DiaA must be released from DnaA (Keyamura et al. 2009). The DiaA-binding site of DnaA domain $\mathrm{I}$ is also used to bind DnaB helicase. However, the mechanism of DiaA-DnaA dissociation has not yet been elucidated.

DiaA orthologs are evolutionarily conserved in bacterial species (Keyamura et al. 2007). In addition, the HobA protein of Helicobacter pylori $(\mathrm{Hp})$, a member of $\varepsilon$-Proteobacteria, displays functional and structural similarity to DiaA, although there is no significant sequence similarity (Table 1) (Natrajan et al. 2007, 2009; Zakrzewsak-Czerwinska et al. 2007; Zawilak-Pawlik et al. 2007, 2011; Terradot et al. 2010).
Regulation of the DnaA Nucleotide Form by RIDA

After ATP-DnaA promotes replication initiation, it is hydrolyzed in a manner dependent on a complex consisting of ADP-Hda protein and the DNA-loaded clamp (Fig. 4; Table 1) (Katayama et al. 1998; Kato and Katayama 2001; Su'etsugu et al. 2008). The resultant ADP-DnaA is inactive in initiation. This system is termed RIDA (regulatory inactivation of DnaA). RIDA is crucial for DnaA inactivation and thereby effectively supports once-per-generation initiation (Kurokawa et al. 1999; Camara et al. 2005; Riber et al. 2009). The hda gene is required for promoting cell proliferation, decreasing cellular ATP-DnaA levels and repressing overinitiation (Kato and Katayama 2001; Fujimitsu et al. 2008; Charbon et al. 2011). Incubation of temperature-sensitive $h d a$ mutant cells at the restrictive temperature leads to overinitiation of replication and induces inhibition of cell division, producing filamentous cells (Fujimitsu et al. 2008). Inhibition of cell division is thought to be a consequence of checkpoint regulation, but the exact mechanism by which this occurs remains unknown. DnaA $\mathrm{AAA}^{+}$sensor II motif Arg-334 is specifically required for ATP-DnaA hydrolysis and expression of a DnaA R334A mutant protein causes overinitiation and inhibition of cell growth in an oriC-dependent manner (Table 1) (Nishida et al. 2002).

Hda protein consists of a short amino-terminal region containing the clamp-binding motif and an $\mathrm{AAA}^{+}$domain that is homologous to DnaA domain III (Fig. 4) (Dalrymple et al. 2001; Kato and Katayama 2001; Kurz et al. 2004; Su'etsugu et al. 2005; Xu et al. 2009). The Hda clamp-binding motif is commonly present in clamp-binding proteins such as DNA polymerase III core subunit $\alpha$ (Dalrymple et al. 2001). It binds to the hydrophobic pocket of the clamp, which is the same site to which DNA polymerase III subunit $\alpha$ binds (Dalrymple et al. 2001; Kurz et al. 2004; Su'etsugu et al. 2005). The Hda $\mathrm{AAA}^{+}$domain specifically binds ADP, but not ATP (Su' etsugu et al. 2008). ADP-Hda is monomeric and active in RIDA, whereas apo-Hda is multimeric and inactive in RIDA (Su'etsugu 
Regulating DNA Replication in Bacteria

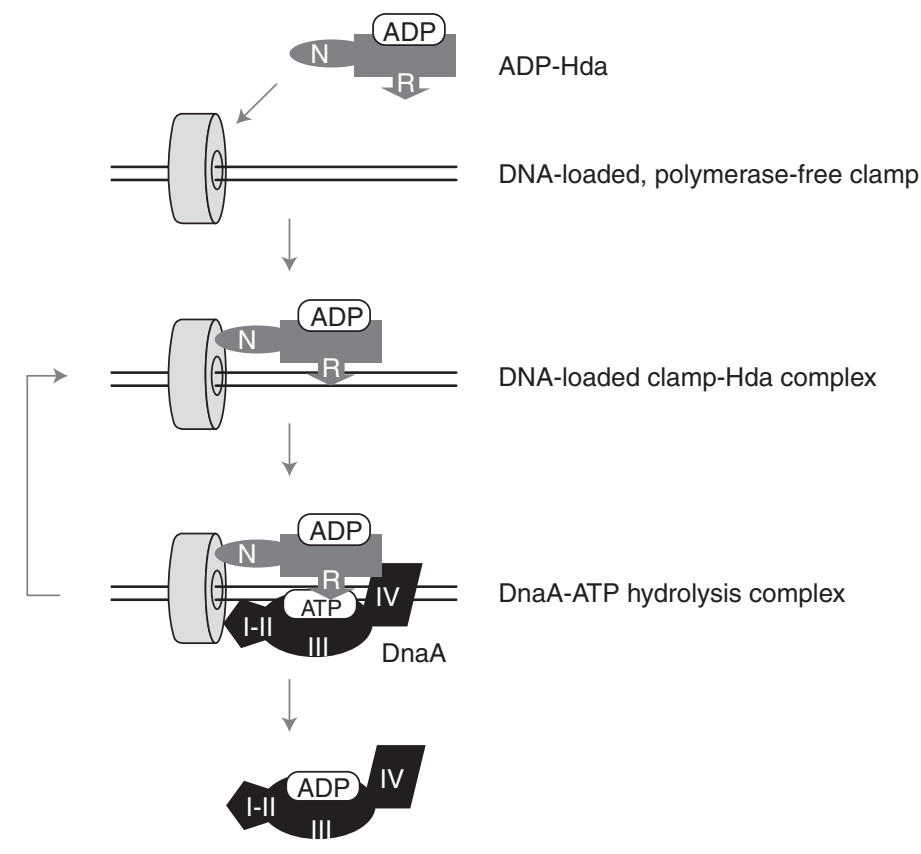

Figure 4. The basic mechanism of RIDA. When DNA polymerase III holoenzyme completes Okazaki fragment synthesis on the lagging strand, the clamp subunit is released from the DNA polymerase III core and remains on the synthesized DNA. ADP-Hda binds to the hydrophobic pocket of the DNA-loaded form of the clamp via the clamp-binding motifs in the amino terminus of Hda. The resultant ADP-Hda-clamp-DNA complex interacts with and promotes the DnaA-bound ATP hydrolysis, releasing ADP-DnaA back into the DnaA cycle. The interaction between the $\mathrm{AAA}^{+}$domains of $\mathrm{Hda}$ and $\mathrm{DnaA}$ is crucial, and is assisted by the interaction between Hda and DnaA domain IV (DNA-binding domain). N, Hda-amino terminus; I-II, DnaA domain I-II; III, DnaA domain III ( $\mathrm{AAA}^{+}$domain); IV, DnaA domain IV (DNA-binding domain).

et al. 2008). The Hda $\mathrm{AAA}^{+}$domain bears a specific Arg residue (i.e., Arg finger) that is crucial for promoting DnaA-ATP hydrolysis (Su'etsugu et al. 2005). This residue may participate in forming the ATP hydrolysis catalytic center by direct DnaA-Hda interaction. This is a common characteristic of many $\mathrm{AAA}^{+}$proteins (Neuwald et al. 1999; Ogura et al. 2004; Indiani and O'Donnell 2006). In addition to the Arg finger, specific residues within the $\mathrm{AAA}^{+}$domains of DnaA and Hda are required for DnaA-Hda interaction and DnaA-ATP hydrolysis (Nakamura et al. 2010). DnaA domain IV (DNA binding domain) promotes this interaction by binding to Hda (Fig. 4) (Keyamura and Katayama 2011).

During DNA elongation, the clamps remain on the lagging strand after Okazaki fragments are synthesized and the DNA polymerase III core is released (Yuzhakov et al. 1996; Balakrishnan and Bambara 2013; Goodman and Woodgate 2013; Hedglin et al. 2013; MacAlpine and Almouzni 2013). DNA-loaded, DNA polymerase-free clamps bind ADP-Hda, resulting in the activation of RIDA (Su'etsugu et al. 2004, 2008). In addition, it is possible that because a clamp is a homodimer, Hda and DNA polymerase III subunit $\alpha$ bind to each protomer of the same clamp to allow Hda to hydrolyze DnaA-ATP as soon as replication forks are under way (Johnsen et al. 2011). DNA-free clamps are inactive in RIDA, although they can bind Hda, which ensures the timely and replication-coupled activation of RIDA. The dsDNA region flanking the clamp is required for RIDA, and may be recognized by DnaA (Fig. 4) (Su'etsugu et al. 2004).

The ADP-Hda-clamp-DNA complex is stable, whereas the affinity of this complex for DnaA is weak (Su'etsugu et al. 2008). This is 
consistent with the fact that the complex is reused for cyclically interacting with multiple ATP-DnaA molecules, and that there are only about 100 Hda molecules per cell (Katayama et al. 2010).

The main principle of RIDA, which is the use of DNA-loaded clamps for replication-coupled negative feedback to the initiator protein, is evolutionarily conserved from bacteria to eukaryotes, including yeast, Xenopus, and human cells (Table 1) (Katayama et al. 2010; Zielke et al. 2012).

\section{Coordination of Regulation for oriC and DnaA}

SeqA binds to hemimethylated oriC immediately after initiation and replication of the oriC region. In a culture with a doubling time of $30 \mathrm{~min}$, the binding of SeqA to oriC lasts for about 10 min. The ratio of ATP-DnaA to ADP-DnaA peaks at initiation, and then undergoes a gradual decrease because of RIDA activity. It takes approximately $15 \mathrm{~min}$ to decrease this ratio to the lowest levels, and probably less than $10 \mathrm{~min}$ to decrease the ratio enough to prevent initiation from occurring when the origins are released after $10 \mathrm{~min}$ of sequestration. Thus, SeqA inactivates oriC early during the inter-initiation period, whereas RIDA represses the DnaA initiation activity for the remainder of this period. Coordination of these two steps is crucial for repressing untimely initiation events (Fig. 3) (Lu et al. 1994; Kurokawa et al. 1999; Skarstad and Løbner-Olesen 2003; Katayama et al. 2010). During multifork replication, in which replication goes on continuously and only the number of replication forks under way changes through the cycle (Fig. 1), it could be that RIDA needs to be temporarily inhibited to achieve a high enough ratio of ATP-DnaA to ADP-DnaA at initiation. Whether such a temporary inhibition occurs remains to be elucidated.

The balance between Dam methylase and SeqA activities governs the duration of the sequestration period (Bach et al. 2003). If Dam methylase is overexpressed, extra rounds of replication occur (Boye and Løbner-Olesen 1990), indicating that high levels of Dam methylase shorten the sequestration period, resulting in origin availability before the initiation potential has dropped (Skarstad and Løbner-Olesen 2003). Likewise, if DnaA is overexpressed or DnaA inactivation by RIDA has not occurred, extra rounds of DNA replication occur because the initiation window has stretched beyond the sequestration window (Atlung et al. 1987; Skarstad et al. 1989; Nishida et al. 2002; Camara et al. 2003).

Regulation of replication initiation in E. coli does not involve control over the concentration of origins. All origins present in the cell are initiated at the same time once per generation irrespective of how many there are. This can be seen when minichromosomes ( plasmids dependent on an oriC sequence for replication initiation) are present in the cell; they initiate at the same time as the chromosomal oriCs (Helmstetter and Leonard 1987; Løbner-Olesen 1999). Thus, the mechanism is the following: all origins are initiated during a short time interval and all new origins are sequestered until initiation is no longer possible. Although replication fork speed can vary significantly (Morigen et al. 2009; Odsbu et al. 2009; Stokke et al. 2012), it is not known whether the speed of each individual replication fork is regulated. In Bacillus subtilis, it has been found that replication elongation can be regulated by ppGpp (Wang et al. 2007) and metabolic enzymes (Janniere et al. 2007).

Regulation of oriC and DnaA in B. subtilis and $C$. crescentus

\section{Regulation by the Clamp-Binding Protein}

Bacillus subtilis (Bs) is a representative of Grampositive bacteria and is a member of Firmicutes, whereas E. coli is representative of Gram-negative bacteria and is a member of $\gamma$-Proteobacteria. This means that these species are evolutionarily distant. In $B$. subtilis, the dnaA gene is located between the clusters of the cognate DnaA boxes on the genome (Messer 2002) that form the replication origin (Moriya et al. 1992, 1994; Krause et al. 1997; and see Leonard and Méchali 2013) and $d n a A$ gene transcription is autoregulated like in E. coli (Table 1) (Ogura et al. 2001). 
Subcellular localization analysis indicates that a considerable number of BsDnaA molecules are titrated to the replication forks in a clamp- and YabA-dependent manner (NoirotGros et al. 2006; Soufo et al. 2008; Goranov et al. 2009). Although YabA has no sequence similarity to E. coli Hda, it binds the clamp and BsDnaA, like Hda (Table 1) (Noirot-Gros et al. 2006; Cho et al. 2008). The YabA-clamp system is required to repress overinitiation of replication (Noirot-Gros et al. 2006; Soufo et al. 2008; Goranov et al. 2009), which may be sustained by the sequestration of many DnaA molecules from oriC. Whether DNA-clamp-YabA complexes induce BsDnaA-ATP hydrolysis is not yet known.

Caulobacter crescentus $(C c)$ is an $\alpha$-Proteobacterial species that is evolutionarily distant from both E. coli and B. subtilis. C. crescentus cells undergo asymmetrical cell division, yielding a stalked cell and a swarmer cell; only a stalked cell can replicate the chromosome whereas a swarmer cell must first differentiate into a stalked cell before replication can occur (Marczynski and Shapiro 2002). In C. crescentus, HdaA, the E. coli Hda ortholog, colocalizes with replisomes and is required to repress overinitiation (Table 1) (Collier and Shapiro 2009). CcDnaA Arg-357 corresponds to the E. coli DnaA $\mathrm{AAA}^{+}$sensor II motif Arg-334, and, like E. coli DnaA R334A, CcDnaA R357A can cause overinitiation of the cognate chromosomal replication (FernandezFernandez et al. 2011). Taken together, the data indicate that replication-dependent DnaA-ATP hydrolysis is important for repressing $C c \mathrm{DnaA}$ activity and extra initiation events.

\section{Regulation by oriC-Binding and Various Factors}

In B. subtilis, the chromosome partition proteins Soj and Spo0J play regulatory roles in replication initiation at oriC (Ogura et al. 2003; Lee and Grossman 2006; Murray and Errington 2008; Scholefield et al. 2011). Soj and Spo0J are members of the same protein family as ParA and ParB that are plasmid-partitioning proteins. The ParS region is a centromere-like region located near ori $C$ and partitions the sister ori $C$ regions by binding to both Soj and Spo0J. DNA-free Soj binds to DnaA assembled on oriC, and represses untimely initiation events (Table 1). ATP-bound Soj binds to ParS and stimulates initiation. Spo0J negatively regulates this Soj action by stimulating Soj-ATP hydrolysis and dissociation from the DNA (Murray and Errington 2008; Scholefield et al. 2011). In addition, the binding of BsDnaA to DnaA box clusters near oriC is also important for preventing premature initiation (Okumura et al. 2012). Similar role for DnaA box clusters is also found in Streptomyces (Table 1) (Smulczyk-Krawczyszyn et al. 2006).

When B. subtilis cells sporulate, the initiation of chromosome replication is inhibited by SirA (Wagner et al. 2009; Rahn-Lee et al. 2011). SirA is expressed specifically on sporulation and binds BsDnaA, which inhibits BsDnaA-oriC binding. E. coli does not contain homologs of Soj, Spo0J, and SirA, whereas B. subtilis does not contain homologs of SeqA and Dam (Table 1).

In C. crescentus, CtrA is a major cell cycledependent transcriptional regulator present in swarmer cells. It binds to the cognate oriC, thereby inhibiting replication initiation (Table 1) (Quan et al. 1998). ClpP degrades CtrA when swarmer cells differentiate into stalked cells (Gorbatyok and Marczynski 2005; McGrath et al. 2006). Homologs of SeqA and Dam are absent in this bacterium.

The Stringent response is activated on carbon starvation and primarily inhibits transcription (Strivatsan and Wang 2008). Carbon starvation activates the synthesis of ppGpp from GDP by RelA or SpoT. ppGpp directly binds to RNA polymerase and alters transcription modes, specifically repressing stable RNA (rRNA and tRNA) synthesis. In E. coli, the initiation of chromosomal replication is inhibited on carbon starvation, which may be caused by changes in RNA polymerase function (Zyskind and Smith 1992) but the entire mechanism is not revealed. In B. subtilis, elongation, but not initiation, is inhibited on carbon starvation, which is indicated to be caused by ppGpp-dependent inactivation of primase (Wang et al. 2007). Similar mechanisms may also exist in E. coli (Maciag et al. 2010). In C. crescentus, SpoT, the ppGpp synthetase, degrades DnaA on carbon starvation (Lesyley and Shapiro 2008). 


\section{CONCLUDING REMARKS}

Multiple systems regulate oriC and DnaA in a concerted manner to ensure that replication initiation occurs only once per origin per generation. Some of these regulatory systems are coupled with specific events that are important for cell cycle regulation or chromosomal replication. In $E$. coli, oriC becomes hemimethylated temporarily just after initiation, which allows the binding of SeqA, an inhibitor of initiation. The DNA-loaded clamps bind Hda protein, and the resultant complexes stimulate DnaA-ATP hydrolysis, thereby inactivating DnaA. This clampdependent feedback regulation is also conserved in eukaryotes. Also, dnaA gene transcription is repressed in a SeqA-dependent and temporal manner. These three negative-feedback mechanisms regulate initiation in a replication-dependent manner in E. coli. In addition, excessive DnaA molecules are titrated to the datA locus on the chromosome, which adds another level of negative regulation. $d n a A$ transcription is also autoregulated in both E. coli and B. subtilis. DARS reactivates DnaA by stimulating ADPto-ATP exchange, thereby supporting timely initiation as well as the DnaA-DiaA interaction.

The B. subtilis clamp-YabA complex and the $C$. crescentus clamp-HdaA complex regulate initiation in a replication-dependent, negativefeedback manner. YabA and HdaA are considered to be the functional homologs of E. coli $\mathrm{Hda}$, but only HdaA displays structural similarity with Hda. In B. subtilis, the ordered interaction of Soj, Spo0J, and the parS locus regulates the initiation activity and assembly of BsDnaA at ori $C$ in a cell cycle-coordinated manner. Like E. coli dat A, DnaA box clusters near oriC are also important for repressing initiation potential. SirA, which is expressed specifically before sporulation, inhibits the binding of BsDnaA to oriC. In C. crescentus, the cell cycle-specific binding of CtrA to the origin may regulate initiation. The stringent response, which is induced on carbon starvation and increases the level of ppGpp, an RNA polymerase inhibitor, stimulates DnaA degradation in C. crescentus, and inhibits elongation in B. subitilis through the ppGpp-primase interaction and initiation in E. coli.

\section{REFERENCES}

* Reference is also in this collection.

Abe Y, Jo T, Matsuda Y, Matsunaga C, Katayama T, Ueda T. 2007. Structure and function of DnaA N-terminal domains: Specific sites and mechanisms in inter-DnaA interaction and in DnaB helicase loading on oriC. $J$ Biol Chem 282: 17816-17827.

Atlas JC, Nikolaev EV, Browning ST, Shuler ML. 2008. Incorporating genome-wide DNA sequence information into a dynamic whole-cell model of Escherichia coli: Application to DNA replication. IET Syst Biol 2: 369-382.

Atlung T, Lobner-Olesen A, Hansen FG. 1987. Overproduction of DnaA protein stimulates initiation of chromosome and minichromosome replication in Escherichia coli. Mol Gen Genet 206: 51-59.

Bach T, Skarstad K. 2005. An oriC-like distribution of GATC sites mediates full sequestration of non-origin sequences in Escherichia coli. J Mol Biol 350: 7-11.

Bach T, Krekling MA, Skarstad K. 2003. Excess SeqA prolongs sequestration of oriC and delays nucleoid segregation and cell division. EMBO J 22: 315-323.

Bach T, Morigen, Skarstad K. 2008. The initiator protein DnaA contributes to keeping new origins inactivated by promoting the presence of hemimethylated DNA. J Mol Biol 384: 1076-1085.

Baker TA, Kornberg A. 1988. Transcriptional activation of initiation of replication from the E. coli chromosome origin: An RNA-DNA hybrid near oriC. Cell 55: 113123.

* Balakrishnan L, Bambara RA. 2013. Okazaki fragment metabolism. Cold Spring Harb Perspect Biol doi: 10.1101/ cshperspect.a010173.

Bates DB, Asai T, Cao Y, Chambers MW, Cadwell GW, Boye E, Kogoma T. 1995. The DnaA box R4 in the minimal oriC is dispensable for initiation of Escherichia coli chromosome replication. Nucleic Acids Res 23: 31193125 .

Bates DB, Boye E, Asai T, Kogoma T. 1997. The absence of effect of gid or mioC transcription on the initiation of chromosomal replication in Escherichia coli. Proc Natl Acad Sci 94: 12497-12502.

* Bell SP, Kaguni JM. 2013. Helicase loading at chromosomal origins of replication. Cold Spring Harb Perspect Biol doi: 10.1101/cshperspect.a010124.

Bogan JA, Helmstetter CE. 1997. DNA sequestration and transcription in the oriC region of Escherichia coli. Mol Microbiol 26: 889-896.

Boye E, Lobner-Olesen A. 1990. The role of dam methyltransferase in the control of DNA replication in E. coli. Cell 62: 981-989.

Boye E, Stokke T, Kleckner N, Skarstad K. 1996. Coordinating DNA replication initiation with cell growth: Differential roles for DnaA and SeqA proteins. Proc Natl Acad Sci 93: 12206-12211.

Brendler T, Austin S. 1999. Binding of SeqA protein to DNA requires interaction between two or more complexes bound to separate hemimethylated GATC sequences. EMBO J 18: 2304-2310.

Brendler T, Sawitzke J, Sergueev K, Austin S. 2000. A case for sliding SeqA tracts at anchored replication forks during 
Escherichia coli chromosome replication and segregation. EMBO J 19: 6249-6258.

Browning ST, Castellanos M, Shuler ML. 2004. Robust control of initiation of prokaryotic chromosome replication: Essential considerations for a minimal cell. Biotechnol Bioeng 88: 575-584.

Camara JE, Breier AM, Brendler T, Austin S, Cozzarelli NR, Crooke E. 2005. Hda inactivation of DnaA is the predom inant mechanism preventing hyperinitiation of Escherichia coli DNA replication. EMBO Rep 6: 736-741.

Campbell JL, Kleckner N. 1990. E coli oriC and the dnaA gene promoter are sequestered from dam methyltransferase following the passage of the chromosomal replication fork. Cell 62: 967-979.

Cassler MR, Grimwade JE, Leonard AC. 1995. Cell cyclespecific changes in nucleoprotein complexes at a chromosomal replication origin. EMBO J 14: 5833-5841.

Charbon G, Riber L, Cohen M, Skovgaard O, Fujimitsu K, Katayama T, Lobner-Olesen A. 2011. Suppressors of DnaA(ATP) imposed overinitiation in Escherichia coli. Mol Microbiol 79: 914-928.

Chiaramello A, Zyskind JW. 1989. Expression of Escherichia coli $d n a A$ and mioC genes as a function of growth rate. J Bacteriol 171: 4272-4280.

Cho E, Ogasawara N, Ishikawa S. 2008. The functional analysis of YabA, which interacts with DnaA and regulates initiation of chromosome replication in Bacillus subtilis. Genes Genet Syst 83: 111-125.

Collier J, Shapiro L. 2009. Feedback control of DnaA-mediated replication initiation by replisome-associated $\mathrm{HdaA}$ protein in Caulobacter. J Bacteriol 191: 5706-5716.

Crooke E, Castuma CE, Kornberg A. 1992. The chromosome origin of Escherichia coli stabilizes DnaA protein during rejuvenation by phospholipids. J Biol Chem 267: 16779-16782.

Dalrymple BP, Kongsuwan K, Wijffels G, Dixon NE, Jennings PA. 2001. A universal protein-protein interaction motif in the eubacterial DNA replication and repair system. Proc Natl Acad Sci 98: 11627-11632.

Dillon SC, Dorman CJ. 2010. Bacterial nucleoid-associated proteins, nucleoid structure and gene expression. Nat Rev Microbiol 8: 185-195.

Donachie WD, Blakely GW. 2003. Coupling the initiation of chromosome replication to cell size in Escherichia coli. Curr Opin Microbiol 6: 146-150.

Duderstadt KE, Berger JM. 2008. AAA ${ }^{+}$ATPases in the initiation of DNA replication. Crit Rev Biochem Mol Biol 43: $163-187$.

Duderstadt KE, Chuang K, Berger JM. 2011. DNA stretching by bacterial initiators promotes replication origin opening. Nature 478: 209-213.

Erzberger JP, Mott ML, Berger JM. 2006. Structural basis for ATP-dependent DnaA assembly and replication-origin remodeling. Nat Struct Mol Biol 13: 676-683.

Fernandez-Fernandez C, Gonzalez D, Collier J. 2011. Regulation of the activity of the dual-function DnaA protein in Caulobacter crescentus. PLoS ONE 6: e26028.

Flatten I, Morigen, Skarstad K. 2009. DnaA protein interacts with RNA polymerase and partially protects it from the effect of rifampicin. Mol Microbiol 71: 1018-1030.
Fossum S, Crooke E, Skarstad K. 2007. Organization of sister origins and replisomes during multifork DNA replication in Escherichia coli. EMBO J 26: 4514-4522.

Fujikawa N, Kurumizaka H, Nureki O, Terada T, Shirouzu M, Katayama T, Yokoyama S. 2003. Structural basis of replication origin recognition by the DnaA protein. Nucleic Acids Res 31: 2077-2086.

Fujikawa N, Kurumizaka H, Nureki O, Tanaka Y, Yamazoe M, Hiraga S, Yokoyama S. 2004. Structural and biochemical analyses of hemimethylated DNA binding by the SeqA protein. Nucleic Acids Res 32: 82-92.

Fujimitsu K, Su'etsugu M, Yamaguchi Y, Mazda K, Fu N, Kawakami H, Katayama T. 2008. Modes of overinitiation, $d n a A$ gene expression, and inhibition of cell division in a novel cold-sensitive $h d a$ mutant of Escherichia coli. J Bacteriol 190: 5368-5381.

Fujimitsu K, Senriuchi T, Katayama T. 2009. Specific genomic sequences of $E$. coli promote replicational initiation by directly reactivating ADP-DnaA. Genes Dev 23: 12211233.

Gille H, Egan JB, Roth A, Messer W. 1991. The FIS protein binds and bends the origin of chromosomal DNA replication, oriC, of Escherichia coli. Nucleic Acids Res 19: 4167-4172.

* Goodman MF, Woodgate R. 2013. Translesion DNA polymerases. Cold Spring Harb Perspect Biol doi: 10.1101/ cshperspect.a010363.

Goranov AI, Breier AM, Merrikh H, Grossman AD. 2009. YabA of Bacillus subtilis controls DnaA-mediated replication initiation but not the transcriptional response to replication stress. Mol Microbiol 74: 454-466.

Gorbatyuk B, Marczynski GT. 2005. Regulated degradation of chromosome replication proteins DnaA and CtrA in Caulobacter crescentus. Mol Microbiol 55: 1233-1245.

Grimwade JE, Ryan VT, Leonard AC. 2000. IHF redistributes bound initiator protein, DnaA, on supercoiled oriC of Escherichia coli. Mol Microbiol 35: 835-844.

Guarne A, Zhao Q, Ghirlando R, Yang W. 2002. Insights into negative modulation of $E$. coli replication initiation from the structure of SeqA-hemimethylated DNA complex. Nat Struct Biol 9: 839-843.

Guarne A, Brendler T, Zhao Q, Ghirlando R, Austin S, Yang W. 2005. Crystal structure of a SeqA-N filament: Implications for DNA replication and chromosome organization. EMBO J 24: 1502-1511.

Hansen FG, Atlung T, Braun RE, Wright A, Hughes P, Kohiyama M. 1991a. Initiator (DnaA) protein concentration as a function of growth rate in Escherichia coli and Salmonella typhimurium. J Bacteriol 173: 5194-5199.

Hansen FG, Christensen BB, Atlung T. 1991b. The initiator titration model: Computer simulation of chromosome and minichromosome control. Res Microbiol 142: 161167.

Hansen FG, Christensen BB, Atlung T. 2007. Sequence characteristics required for cooperative binding and efficient in vivo titration of the replication initiator protein DnaA in E. coli. J Mol Biol 367: 942-952.

* Hedglin M, Kumar R, Benkovic SJ. 2013. Replication clamps and clamp loaders. Cold Spring Harb Perspect Biol doi: 10.1101/cshperspect.a010165. 
Helmstetter C. 1996. Timing of synthetic activities in the cell cycle. In Escherichia coli and Salmonella: Cellular and molecular biology, 2nd ed. (ed. Neidhardt FC, Curtiss R III, Ingraham JL, Lin ECC, Low KB, Magasanik B, Reznikoff WS, Riley M, Schaechter M, Umbarger HE), pp. 1627-1639. ASM Press, Washington, DC.

Helmstetter CE, Leonard AC. 1987. Coordinate initiation of chromosome and minichromosome replication in Escherichia coli. J Bacteriol 169: 3489-3494.

Hiasa H, Marians KJ. 1994. Fis cannot support oriC DNA replication in vitro. J Biol Chem 269: 24999-25003.

Hiraga S. 2000. Dynamic localization of bacterial and plasmid chromosomes. Annu Rev Genet 34: 21-59.

Hiraga S, Ichinose C, Niki H, Yamazoe M. 1998. Cell cycledependent duplication and bidirectional migration of SeqA-associated DNA-protein complexes in E. coli. Mol Cell 1: 381-387.

Hwang DS, Kornberg A. 1992. Opening of the replication origin of Escherichia coli by DnaA protein with protein HU or IHF. J Biol Chem 267: 23083-23086.

Indiani C, O'Donnell M. 2006. The replication clamp-loading machine at work in the three domains of life. Nat Rev Mol Cell Biol 7: 751-761.

Ishida T, Akimitsu N, Kashioka T, Hatano M, Kubota T, Ogata Y, Sekimizu K, Katayama T. 2004. DiaA, a novel DnaA-binding protein, ensures the timely initiation of Escherichia coli chromosome replication. J Biol Chem 279: 45546-45555.

Janniere L, Canceill D, Suski C, Kanga S, Dalmais B, Lestini R, Monnier AF, Chapuis J, Bolotin A, Titok M, et al. 2007. Genetic evidence for a link between glycolysis and DNA replication. PLOS ONE 2: e447.

Johnsen L, Flatten I, Morigen, Dalhus B, Bjoras M, Waldminghaus T, Skarstad K. 2011. The G157C mutation in the Escherichia coli sliding clamp specifically affects initiation of replication. Mol Microbiol 79: 433-446.

Kaguni JM. 2011. Replication initiation at the Escherichia coli chromosomal origin. Curr Opin Chem Biol 15: 606613.

Kang S, Han JS, Kim KP, Yang HY, Lee KY, Hong CB, Hwang DS. 2005. Dimeric configuration of SeqA protein bound to a pair of hemi-methylated GATC sequences. Nucleic Acids Res 33: 1524-1531.

Katayama T, Kubota T, Kurokawa K, Crooke E, Sekimizu K. 1998. The initiator function of DnaA protein is negatively regulated by the sliding clamp of the E. coli chromosomal replicase. Cell 94: 61-71.

Katayama T, Ozaki S, Keyamura K, Fujimitsu K. 2010. Regulation of the replication cycle: conserved and diverse regulatory systems for DnaA and oriC. Nat Rev Microbiol 8: $163-170$.

Kato J, Katayama T. 2001. Hda, a novel DnaA-related protein, regulates the replication cycle in Escherichia coli. EMBO J 20: 4253-4262.

Kawakami H, Katayama T. 2010. DnaA, ORC, and Cdc6: Similarity beyond the domains of life and diversity. Biochem Cell Biol 88: 49-62.

Kawakami H, Keyamura K, Katayama T. 2005. Formation of an ATP-DnaA-specific initiation complex requires DnaA Arginine 285, a conserved motif in the $\mathrm{AAA}^{+}$protein family. J Biol Chem 280: 27420-27430.
Keyamura K, Katayama T. 2011. DnaA protein DNA-binding domain binds to Hda protein to promote inter-AAA ${ }^{+}$ domain interaction involved in regulatory inactivation of DnaA. J Biol Chem 286: 29336-29346.

Keyamura K, Fujikawa N, Ishida T, Ozaki S, Su'etsugu M, Fujimitsu K, Kagawa W, Yokoyama S, Kurumizaka H, Katayama T. 2007. The interaction of DiaA and DnaA regulates the replication cycle in E. coli by directly promoting ATP DnaA-specific initiation complexes. Genes Dev 21: 2083-2099.

Keyamura K, Abe Y, Higashi M, Ueda T, Katayama T. 2009. DiaA dynamics are coupled with changes in initial origin complexes leading to helicase loading. J Biol Chem 284: 25038-25050.

Kitagawa R, Mitsuki H, Okazaki T, Ogawa T. 1996. A novel DnaA protein-binding site at $94.7 \mathrm{~min}$ on the Escherichia coli chromosome. Mol Microbiol 19: 1137-1147.

Kitagawa R, Ozaki T, Moriya S, Ogawa T. 1998. Negative control of replication initiation by a novel chromosomal locus exhibiting exceptional affinity for Escherichia coli DnaA protein. Genes Dev 12: 3032-3043.

Kornberg A, Baker TA. 1992. DNA replication, 2nd ed. W. H. Freeman, New York.

Krause M, Ruckert B, Lurz R, Messer W. 1997. Complexes at the replication origin of Bacillus subtilis with homologous and heterologous DnaA protein. J Mol Biol 274: 365-380.

Kurokawa K, Nishida S, Emoto A, Sekimizu K, Katayama T. 1999. Replication cycle-coordinated change of the adenine nucleotide-bound forms of DnaA protein in Escherichia coli. EMBO J 18: 6642-6652.

Kurz M, Dalrymple B, Wijffels G, Kongsuwan K. 2004. Interaction of the sliding clamp $\beta$-subunit and $\mathrm{Hda}$, a DnaA-related protein. J Bacteriol 186: 3508-3515.

Lee PS, Grossman AD. 2006. The chromosome partitioning proteins Soj (ParA) and Spo0J (ParB) contribute to accurate chromosome partitioning, separation of replicated sister origins, and regulation of replication initiation in Bacillus subtilis. Mol Microbiol 60: 853-869.

Lee H, Kang S, Bae SH, Choi BS, Hwang DS. 2001. SeqA protein aggregation is necessary for SeqA function. J Biol Chem 276: 34600-34606.

Leonard AC, Grimwade JE. 2005. Building a bacterial orisome: Emergence of new regulatory features for replication origin unwinding. Mol Microbiol 55: 978-985.

Leonard AC, Grimwade JE. 2009. Initiating chromosome replication in E. coli: It makes sense to recycle. Genes Dev 23: 1145-1150.

Leonard AC, Grimwade JE. 2011. Regulation of DnaA assembly and activity: Taking directions from the genome. Annu Rev Microbiol 65: 19-35.

* Leonard AC, Méchali M. 2013. DNA replication origins. Cold Spring Harb Perspect Biol doi: 10.1101/cshperspect.a010116.

Lesley JA, Shapiro L. 2008. SpoT regulates DnaA stability and initiation of DNA replication in carbon-starved Caulobacter crescentus. J Bacteriol 190: 6867-6880.

Lobner-Olesen A. 1999. Distribution of minichromosomes in individual Escherichia coli cells: Implications for replication control. EMBO J 18: 1712-1721. 
Lu M, Campbell JL, Boye E, Kleckner N. 1994. SeqA: A negative modulator of replication initiation in E. coli. Cell 77: 413-426.

* MacAlpine DM, Almouzni G. 2013. Chromatin and DNA replication. Cold Spring Harb Perspect Biol doi: 10.1101/ cshperspect.a010207.

Maciag M, Kochanowska M, Lyzen R, Wegrzyn G, Szalewska-Palasz A. 2010. ppGpp inhibits the activity of Escherichia coli DnaG primase. Plasmid 63: 61-67.

Marczynski GT, Shapiro L. 2002. Control of chromosome replication in Caulobacter crescentus. Annu Rev Microbiol 56: $625-656$.

Margulies C, Kaguni JM. 1998. The FIS protein fails to block the binding of DnaA protein to oriC, the Escherichia coli chromosomal origin. Nucleic Acids Res 26: 5170-5175.

McGarry KC, Ryan VT, Grimwade JE, Leonard AC. 2004. Two discriminatory binding sites in the Escherichia coli replication origin are required for DNA strand opening by initiator DnaA-ATP. Proc Natl Acad Sci 101: 28112816.

McGrath PT, Iniesta AA, Ryan KR, Shapiro L, McAdams HH. 2006. A dynamically localized protease complex and a polar specificity factor control a cell cycle master regulator. Cell 124: 535-547.

Messer W. 2002. The bacterial replication initiator DnaA. DnaA and oriC, the bacterial mode to initiate DNA replication. FEMS Microbiol Rev 26: 355-374.

Messer W, Weigel C. 1997. DnaA initiator-also a transcription factor. Mol Microbiol 24: 1-6.

Molina F, Skarstad K. 2004. Replication fork and SeqA focus distributions in Escherichia coli suggest a replication hyperstructure dependent on nucleotide metabolism. Mol Microbiol 52: 1597-1612.

Morigen, Lobner-Olesen A, Skarstad K. 2003. Titration of the Escherichia coli DnaA protein to excess datA sites causes destabilization of replication forks, delayed replication initiation and delayed cell division. Mol Microbiol 50: $349-362$.

Morigen, Molina F, Skarstad K. 2005. Deletion of the datA site does not affect once-per-cell-cycle timing but induces rifampin-resistant replication. J Bacteriol 187: 3913-3920.

Morigen, Odsbu I, Skarstad K. 2009. Growth rate dependent numbers of SeqA structures organize the multiple replication forks in rapidly growing Escherichia coli. Genes Cells 14: 643-657.

Moriya S, Atlung T, Hansen FG, Yoshikawa H, Ogasawara N. 1992. Cloning of an autonomously replicating sequence (ars) from the Bacillus subtilis chromosome. Mol Microbiol 6: 309-315.

Moriya S, Firshein W, Yoshikawa H, Ogasawara N. 1994 Replication of a Bacillus subtilis oriC plasmid in vitro. Mol Microbiol 12: 469-478.

Murray H, Errington J. 2008. Dynamic control of the DNA replication initiation protein DnaA by Soj/ParA. Cell 135: $74-84$.

Nakamura K, Katayama T. 2010. Novel essential residues of Hda for interaction with DnaA in the regulatory inactivation of DnaA: Unique roles for Hda AAA Box VI and VII motifs. Mol Microbiol 76: 302-317.
Natrajan G, Hall DR, Thompson AC, Gutsche I, Terradot L. 2007. Structural similarity between the DnaA-binding proteins HobA (HP1230) from Helicobacter pylori and DiaA from Escherichia coli. Mol Microbiol 65: 995-1005.

Natrajan G, Noirot-Gros MF, Zawilak-Pawlik A, Kapp U, Terradot L. 2009. The structure of a DnaA/HobA complex from Helicobacter pylori provides insight into regulation of DNA replication in bacteria. Proc Natl Acad Sci 106: $21115-21120$.

Neuwald AF, Aravid L, Spouge JL, Koonin EV. 1999. AAA ${ }^{+}$: A class of chaperon-like ATPases associated with the assembly, operation, and disassembly of protein complexes. Genome Res 9: 27-43.

Nievera C, Torgue JJ, Grimwade JE, Leonard AC. 2006. SeqA blocking of DnaA-oriC interactions ensures staged assembly of the E. coli pre-RC. Mol Cell 24: 581-592.

Nishida S, Fujimitsu K, Sekimizu K, Ohmura T, Ueda T, Katayama T. 2002. A nucleotide switch in the Escherichia coli DnaA protein initiates chromosomal replication: Evidence from a mutant DnaA protein defective in regulatory ATP hydrolysis in vitro and in vivo. J Biol Chem 277: 14986-14995.

Noirot-Gros MF, Velten M, Yoshimura M, McGovern S, Morimoto T, Ehrlich SD, Ogasawara N, Polard P, Noirot P. 2006. Functional dissection of YabA, a negative regulator of DNA replication initiation in Bacillus subtilis. Proc Natl Acad Sci 103: 2368-2373.

Odsbu I, Klungsoyr HK, Fossum S, Skarstad K. 2005. Specific N-terminal interactions of the Escherichia coli SeqA protein are required to form multimers that restrain negative supercoils and form foci. Genes Cells 10: 10391049.

Odsbu I, Morigen, Skarstad K. 2009. A reduction in ribonucleotide reductase activity slows down the chromosome replication fork but does not change its localization. PLoS ONE 4: e7617.

Ogawa T, Okazaki T. 1994. Cell cycle-dependent transcription from the gid and mioC promoters of Escherichia coli. J Bacteriol 176: 1609-1615.

Ogawa T, Yamada Y, Kuroda T, Kishi T, Moriya S. 2002. The datA locus predominantly contributes to the initiator titration mechanism in the control of replication initiation in Escherichia coli. Mol Microbiol 44: 1367-1375.

Ogura Y, Imai Y, Ogasawara N, Moriya S. 2001. Autoregulation of the dnaA-dnaN operon and effects of DnaA protein levels on replication initiation in Bacillus subtilis. J Bacteriol 183: 3833-3841.

Ogura Y, Ogasawara N, Harry EJ, Moriya S. 2003. Increasing the ratio of Soj to Spo0J promotes replication initiation in Bacillus subtilis. J Bacteriol 185: 6316-6324.

Ogura T, Whiteheart SW, Wilkinson AJ. 2004. Conserved arginine residues implicated in ATP hydrolysis, nucleotide-sensing, and inter-subunit interactions in AAA and $\mathrm{AAA}^{+}$ATPases. J Struct Biol 146: 106-112.

Okumura $\mathrm{H}$, Yoshimura M, Ueki M, Oshima T, Ogasawara N, Ishikawa S. 2012. Regulation of chromosomal replication initiation by oriC-proximal DnaA-box clusters in Bacillus subtilis. Nucleic Acids Res 40: 220-234.

Ozaki S, Katayama T. 2009. DnaA structure, function, and dynamics in the initiation at the chromosomal origin. Plasmid 62: 71-82. 
Ozaki S, Katayama T. 2012. Highly organized DnaA-oriC complexes recruit the single-stranded DNA for replication initiation. Nucleic Acids Res 40: 1648-1665.

Ozaki S, Kawakami H, Nakamura K, Fujikawa N, Kagawa W, Park SY, Yokoyama S, Kurumizaka H, Katayama T. 2008. A common mechanism for the ATP-DnaA-dependent formation of open complexes at the replication origin. J Biol Chem 283: 8351-8362.

Quon KC, Yang B, Domian IJ, Shapiro L, Marczynski GT. 1998. Negative control of bacterial DNA replication by a cell cycle regulatory protein that binds at the chromosome origin. Proc Natl Acad Sci 95: 120-125.

Rahn-Lee L, Merrikh H, Grossman AD, Losick R. 2011. The sporulation protein SirA inhibits the binding of DnaA to the origin of replication by contacting a patch of clustered amino acids. J Bacteriol 193: 1302-1307.

Riber L, Lobner-Olesen A. 2005. Coordinated replication and sequestration of oriC and $d n a A$ are required for maintaining controlled once-per-cell-cycle initiation in Escherichia coli. J Bacteriol 187: 5605-5613.

Riber L, Fujimitsu K, Katayama T, Lobner-Olesen A. 2009. Loss of Hda activity stimulates replication initiation from I-box, but not R4 mutant origins in Escherichia coli. Mol Microbiol 71: 107-122.

Roth A, Messer W. 1998. High-affinity binding sites for the initiator protein DnaA on the chromosome of Escherichia coli. Mol Microbiol 28: 395-401.

Ryan VT, Grimwade JE, Nievera CJ, Leonard AC. 2002. IHF and HU stimulate assembly of pre-replication complexes at Escherichia coli oriC by two different mechanisms. Mol Microbiol 46: 113-124.

Ryan VT, Grimwade JE, Camara JE, Crooke E, Leonard AC. 2004. Escherichia coli prereplication complex assembly is regulated by dynamic interplay among Fis, IHF and DnaA. Mol Microbiol 51: 1347-1359.

Scholefield G, Whiting R, Errington J, Murray H. 2011. Spo0J regulates the oligomeric state of Soj to trigger its switch from an activator to an inhibitor of DNA replication initiation. Mol Microbiol 79: 1089-1100.

Seitz H, Weigel C, Messer W. 2000. The interaction domains of the DnaA and DnaB replication proteins of Escherichia coli. Mol Microbiol 37: 1270-1279.

Sekimizu K, Kornberg A. 1988. Cardiolipin activation of $d n a A$ protein, the initiation protein of replication in Escherichia coli. J Biol Chem 263: 7131-7135.

Sekimizu K, Yung BY-M, Kornberg A. 1988. The dnaA protein of Escherichia coli: Abundance, improved purification, and membrane binding. J Biol Chem 263: 71367140.

Skarstad K, Lobner-Olesen A. 2003. Stable co-existence of separate replicons in Escherichia coli is dependent on once-per-cell-cycle initiation. EMBO J 22: 140-150.

Skarstad K, Boye E, Steen HB. 1986. Timing of initiation of chromosome replication in individual Escherichia coli cells. EMBO J 5: 1711-1717.

Skarstad K, Lobner-Olesen A, Atlung T, von Meyenburg K, Boye E. 1989. Initiation of DNA replication in Escherichia coli after overproduction of the DnaA protein. Mol Gen Genet 218: 50-56.

Skarstad K, Baker TA, Kornberg A. 1990. Strand separation required for initiation of replication at the chromosomal origin of E.coli is facilitated by a distant RNA-DNA hybrid. EMBO J 9: 2341-2348

Slater S, Wold S, Lu M, Boye E, Skarstad K, Kleckner N. 1995. E coli SeqA protein binds oriC in two different methyl-modulated reactions appropriate to its roles in DNA replication initiation and origin sequestration. Cell 82: 927-936.

Smulczyk-Krawczyszyn A, Jakimowicz D, Ruban-Osmialowska B, Zawilak-Pawlik A, Majka J, Chater K, Zakrzewska-Czerwinska J. 2006. Cluster of DnaA boxes involved in regulation of Streptomyces chromosome replication: From in silico to in vivo studies. $J$ Bacteriol 188: 6184-6194.

Soufo CD, Soufo HJ, Noirot-Gros MF, Steindorf A, Noirot P, Graumann PL. 2008. Cell-cycle-dependent spatial sequestration of the DnaA replication initiator protein in Bacillus subtilis. Dev Cell 15: 935-941.

Speck C, Messer W. 2001. Mechanism of origin unwinding: Sequential binding of DnaA to double- and singlestranded DNA. EMBO J 20: 1469-1476.

Srivatsan A, Wang JD. 2008. Control of bacterial transcription, translation and replication by (p)ppGpp. Curr Opin Microbiol 11: 100-105.

Stokke C, Flåtten I, Skarstad K. 2012. An easy-to-use simulation program demonstrates variations in bacterial cell cycle parameters depending on medium and temperature. PloS ONE 7: e30981.

Su'etsugu M, Emoto A, Fujimitsu K, Keyamura K, Katayama T. 2003. Transcriptional control for initiation of chromosomal replication in Escherichia coli: Fluctuation of the level of origin transcription ensures timely initiation. Genes Cells 8: 731-745.

Su'etsugu M, Takata M, Kubota T, Matsuda Y, Katayama T. 2004. Molecular mechanism of DNA replication-coupled inactivation of the initiator protein in Escherichia coli: Interaction of DnaA with the sliding clamp-loaded DNA and the sliding clamp-Hda complex. Genes Cells 9: 509-522.

Su'etsugu M, Shimuta TR, Ishida T, Kawakami H, Katayama T. 2005. Protein associations in DnaA-ATP hydrolysis mediated by the Hda-replicase clamp complex. J Biol Chem 280: 6528-6536.

Su'etsugu M, Nakamura K, Keyamura K, Kudo Y, Katayama T. 2008. Hda monomerization by ADP binding promotes replicase clamp-mediated DnaA-ATP hydrolysis. J Biol Chem 283: 36118-36131.

Sutton MD, Carr KM, Vicente M, Kaguni JM. 1998. Escherichia coli DnaA protein. The N-terminal domain and loading of DnaB helicase at the E. coli chromosomal origin. J Biol Chem 273: 34255-34262.

Terradot L, Zawilak-Pawlik A. 2010. Structural insight into Helicobacter pylori DNA replication initiation. Gut Microbes 1: 330-334.

Theisen PW, Grimwade JE, Leonard AC, Bogan JA, Helmstetter CE. 1993. Correlation of gene transcription with the time of initiation of chromosome replication in Escherichia coli. Mol Microbiol 10: 575-584.

Torheim NK, Skarstad K. 1999. Escherichia coli SeqA protein affects DNA topology and inhibits open complex formatiom at oriC. EMBO J 18: 4882-4888. 
Torheim NK, Boye E, Lobner-Olesen A, Stokke T, Skarstad K. 2000. The Escherichia coli SeqA protein destabilizes mutant DnaA204 protein. Mol Microbiol 37: 629-638.

Wagner JK, Marquis KA, Rudner DZ. 2009. SirA enforces diploidy by inhibiting the replication initiator DnaA during spore formation in Bacillus subtilis. Mol Microbiol 73: 963-974.

Waldminghaus T, Skarstad K. 2009. The Escherichia coli SeqA protein. Plasmid 61: 141-150.

Waldminghaus T, Weigel C, Skarstad K. 2012. Replication fork movement and methylation govern SeqA binding to the Escherichia coli chromosome. Nucleic Acids Res 40: 5465-5476.

Wang JD, Sanders GM, Grossman AD. 2007. Nutritional control of elongation of DNA replication by (p)ppGpp. Cell 128: 865-875.

Wold S, Crooke E, Skarstad K. 1996. The Escherichia coli Fis protein prevents initiation of DNA replication from oriC in vitro. Nucleic Acids Res 24: 3527-3532.

Xia W, Dowhan W. 1995. In vivo evidence for the involvement of anionic phospholipid in initiation of DNA replication in Escherichia coli. Proc Natl Acad Sci 92: 783-787.

Xu Q, McMullan D, Abdubek P, Astakhova T, Carlton D, Chen C, Chiu HJ, Clayton T, Das D, Deller MC, et al. 2009. A structural basis for the regulatory inactivation of DnaA. J Mol Biol 385: 368-380.
Yamazoe M, Adachi S, Kanaya S, Ohsumi K, Hiraga S. 2005. Sequential binding of SeqA protein to nascent DNA segments at replication forks in synchronized cultures of Escherichia coli. Mol Microbiol 55: 289-298.

Yuzhakov A, Turner J, O’Donnell M. 1996. Replisome assembly reveals the basis for asymmetric function in leading and lagging strand replication. Cell 86: 877-886.

Zakrzewska-Czerwinska J, Jakimowicz D, Zawilak-Pawlik A, Messer W. 2007. Regulation of the initiation of chromosomal replication in bacteria. FEMS Microbiol Rev 31: 378-387.

Zawilak-Pawlik A, Kois A, Stingl K, Boneca IG, Skrobuk P, Piotr J, Lurz R, Zakrzewska-Czerwinska J, Labigne A. 2007. HobA-a novel protein involved in initiation of chromosomal replication in Helicobacter pylori. Mol Microbiol 65: 979-994.

Zawilak-Pawlik A, Donczew R, Szafranski S, Mackiewicz P, Terradot L, Zakrzewska-Czerwinska J. 2011. DiaA/HobA and DnaA: A pair of proteins co-evolved to cooperate during bacterial orisome assembly. J Mol Biol 408: 238251.

* Zielke N, Edgar BA, DePamphilis ML. 2013. Endoreplication. Cold Spring Harb Perspect Biol 5: a012948.

Zyskind JW, Smith DW. 1992. DNA replication, the bacterial cell cycle, and cell growth. Cell 69: 5-8. 


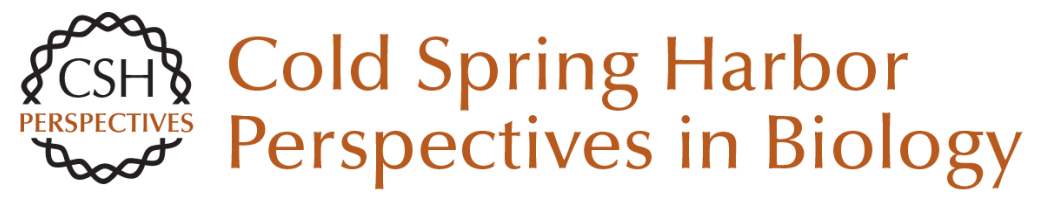

\section{Regulating DNA Replication in Bacteria}

Kirsten Skarstad and Tsutomu Katayama

Cold Spring Harb Perspect Biol 2013; doi: 10.1101/cshperspect.a012922 originally published online March 7, 2013

\section{Subject Collection DNA Replication}

Replication of Epstein-Barr Viral DNA Wolfgang Hammerschmidt and Bill Sugden

Replication Proteins and Human Disease Andrew P. Jackson, Ronald A. Laskey and Nicholas Coleman

Break-Induced DNA Replication Ranjith P. Anand, Susan T. Lovett and James E. Haber

Regulating DNA Replication in Eukarya Khalid Siddiqui, Kin Fan On and John F.X. Diffley

Archaeology of Eukaryotic DNA Replication Kira S. Makarova and Eugene V. Koonin

Translesion DNA Polymerases Myron F. Goodman and Roger Woodgate

Human Papillomavirus Infections: Warts or Cancer?

Louise T. Chow and Thomas R. Broker

Chromatin and DNA Replication

David M. MacAlpine and Geneviève Almouzni
Endoreplication

Norman Zielke, Bruce A. Edgar and Melvin L.

DePamphilis

Replication-Fork Dynamics

Karl E. Duderstadt, Rodrigo Reyes-Lamothe, Antoine M. van Oijen, et al.

Helicase Activation and Establishment of

Replication Forks at Chromosomal Origins of

Replication

Seiji Tanaka and Hiroyuki Araki

Poxvirus DNA Replication Bernard Moss

The Minichromosome Maintenance Replicative Helicase

Stephen D. Bell and Michael R. Botchan

DNA Replication Origins

Alan C. Leonard and Marcel Méchali

Principles and Concepts of DNA Replication in

Bacteria, Archaea, and Eukarya

Michael O'Donnell, Lance Langston and Bruce Stillman

DNA Replication Timing

Nicholas Rhind and David M. Gilbert

For additional articles in this collection, see http://cshperspectives.cshlp.org/cgi/collection/

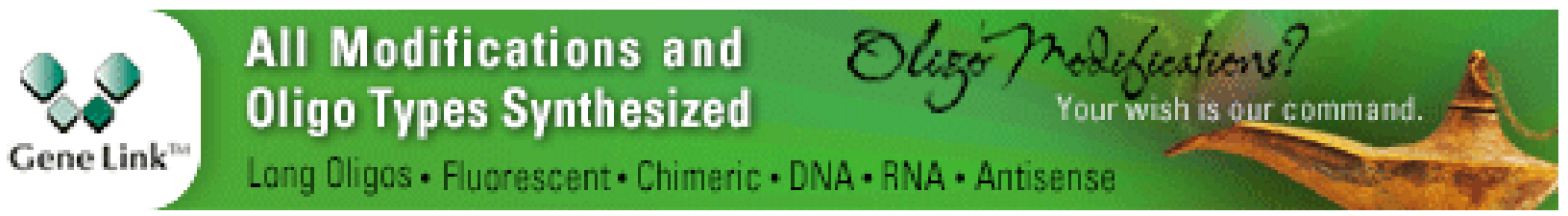

Copyright @ 2013 Cold Spring Harbor Laboratory Press; all rights reserved 